\title{
Influence of Environment on Atmospheric Concentrations of Peronospora antirrhini Sporangia in Field-Grown Snapdragon
}

\author{
J. M. Byrne, Diagnostician and Former Graduate Student, M. K. Hausbeck, Professor, and L. E. Sconyers, \\ Research Associate, Department of Plant Pathology, Michigan State University, East Lansing 48824-1311
}

\begin{abstract}
Byrne, J. M., Hausbeck, M. K., and Sconyers, L. E. 2005. Influence of environment on atmospheric concentrations of Peronospora antirrhini sporangia in field-grown snapdragon. Plant Dis. 89:1060-1066.

Hourly concentrations of airborne sporangia of Peronospora antirrhini at a commercial snapdragon farm were investigated over three growing seasons to determine the influence of the environment on their occurrence and concentration. Hourly concentrations of sporangia of $P$. antirrhini were estimated using a Burkard volumetric spore sampler. Atmospheric sporangial concentrations followed a diurnal pattern and were greatest during 0500 to $1200 \mathrm{~h}$. Minimum daily temperatures $<10.0^{\circ} \mathrm{C}$ appeared to have a moderate limiting effect on atmospheric sporangial concentrations, whereas temperatures $<6.0^{\circ} \mathrm{C}$ had more severe limiting effects. Maximum daily temperatures $\geq 30.0^{\circ} \mathrm{C}$ limited concentrations of atmospheric sporangia. Long dew periods ( $\geq 6 \mathrm{~h}$ ) were associated with relatively large sporangia releases. On 69 days (1999 to 2001), the total number of sporangia trapped was $>100 / \mathrm{m}^{3} /$ day, and the average length of leaf wetness duration prior to these releases was $11 \mathrm{~h}$. Consecutive days with short leaf wetness periods were associated with low atmospheric sporangial concentrations. Significant positive correlations $(P=$ 0.0502 and $P=0.0174$ ) were found between total rainfall and total spore count for both research plots in 2000. Information gained from this study will contribute to the development of a disease management program that utilizes environmental cues to prompt fungicide applications, thus increasing the efficiency of fungicide programs and delaying the development of pathogen resistance.
\end{abstract}

Additional keywords: cut flower, downy mildew

Snapdragon (Antirrhinum majus) plants are grown commercially as a cut-flower crop, with production in the United States occurring primarily in California, Pennsylvania, and Florida. Snapdragon is an annual crop established in the field from transplants that are propagated by seed. Flowers are cut by hand one to two times during the growing season, with the longer-stemmed and more valuable blooms harvested first. Snapdragon had a wholesale value of over $\$ 24$ million dollars in 2002 and 2003 (1). This high-value crop must meet strict requirements for floret size and stem length, with no tolerance for blemishes.

Foliar diseases affect the marketability of snapdragon and include Botrytis blight (Botrytis cinerea), rust (Puccinia antirrhini), powdery mildew (Oidium sp.), and downy mildew (Peronospora antirrhini). Peronospora antirrhini, which causes the

Corresponding author: M. K. Hausbeck

E-mail: hausbec1@msu.edu

This study was supported by funding from the American Floral Endowment.

Accepted for publication 25 May 2005.

DOI: 10.1094/PD-89-1060

(C) 2005 The American Phytopathological Society disease of greatest economic importance, is an obligate pathogen that infects snapdragon foliage locally and systemically (31). Downy mildew can kill terminal buds of young transplants, causing undesirable branching and decreasing the crop value (31). Local infections produce lesions that are visible on the upper leaf surface, whereas systemic infections result in downward curling of foliage, shortened internodes, and plant stunting. A diagnostic sign of downy mildew is the white, grayish sporulation that develops on the undersides of leaves.

Snapdragon cultivars developed for the cut-flower industry vary in susceptibility to downy mildew. 'Potomac Rose', 'Potomac Apple,' and 'Potomac Dark Orange' are significantly less susceptible to downy mildew than 'Rocket White', 'Potomac Ivory,' or 'Potomac Royal' (4). Choosing a more resistant cultivar reduces inoculum load and, when partnered with an effective fungicide program, may enhance overall disease control and flower quality. The use of resistant cultivars has been a downy mildew management strategy with other crops, including lima bean, pumpkin, and radish $(5,7,12,24)$.

Early and frequent scouting is imperative because signs of this downy mildew may go unnoticed on the undersides of leaves, where it develops rapidly. For greenhouse-grown snapdragon, infected plants should be removed to prevent further production and dissemination of spores, and all remaining plants should be treated with preventive fungicides (9). Sprays typically are applied every 1 to 3 weeks throughout the growing season to manage downy mildew. However, calendar-based sprays can lead to fungicide resistance and unnecessary, costly applications. Mancozeb and mancozeb-based products currently are recommended and are applied preventively in alternation with a strobilurin-based fungicide, dimethomorph, fosetyl-Al, or both (9). Development of pathogen resistance to the strobilurins and to fosetyl-Al is of particular concern and has been documented with other downy mildew pathogens $(3,6,11)$.

Crop losses caused by downy mildews can vary greatly among years and seasons. Leaf wetness duration and temperature are known to be critical environmental factors for sporulation, germination, and infection of downy mildews that affect tobacco (Peronospora nicotianae) $(15,22)$, grape (Plasmopara viticola) $(18,19)$, and lettuce (Bremia lactucae) (26-29). Fungicide applications based on environmental cues that trigger downy mildew have been successful for other crops. A warning system for grape downy mildew, based on temperature, leaf wetness duration, and relative humidity, was effective and reduced fungicide sprays (16-18). In California field experiments, the number of fungicide applications for lettuce downy mildew was reduced significantly when sprays were scheduled according to a cumulative leaf wetness threshold (25).

Published research on Peronospora antirrhini to date has been limited to disease symptomology, pathogen morphology, preliminary studies of temperature effects on sporulation, and observations of oospores within plant tissue $(20,33)$. Environmental influences on airborne concentrations of sporangia of $P$. antirrhini have not been studied. The objective of this study was to estimate hourly concentrations of airborne sporangia of $P$. antirrhini among snapdragon plants in a commercial production field and to determine the influence of the environment on their occurrence and concentration. Information gained from this study will contribute to the development of a disease management program that utilizes environmental cues to prompt fungicide applications, thus in- 
creasing the efficiency of fungicide programs and delaying the development of pathogen resistance.

\section{MATERIALS AND METHODS}

This study was conducted in 1999 (2 December 1998 to 13 April 1999), 2000 (22 November 1999 to 5 May 2000), and 2001 (14 December 2000 to 18 April 2001) on a 74.1-ha commercial cut-flower farm in Palm Beach County, FL. Research plots were established within the snapdragon production areas of the farm. There was one research plot in 1999 and 2001 with 176 and 124 beds, respectively. In 2000 , there were two research plots in different areas of the farm, located 106.7 $\mathrm{m}$ apart, with 176 and 88 beds in plots 1 and 2 , respectively. In all years, plants were grown on raised $17.8-\mathrm{cm}$ plant beds (104 $\mathrm{cm}$ by $30.5 \mathrm{~m}$ ) established on $1.5-\mathrm{m}$ centers.

Plot maintenance. Snapdragon seedlings (grown in 288-cell flats) were transplanted from 20 September to 30 November 1998, 11 October to 6 December 1999, and 9 to 26 October 2000. All seedlings within a bed were planted on the same date. A mixture of popular commercial cultivars representing a range of disease susceptibility were planted. Seventeen cultivars were grown: Allure Pink, Allure Red, Attraction Pink, Attraction Rose, Attraction White, Potomac Apple Blossom, Potomac Dark Orange, Potomac Early Pink, Potomac Ivory, Potomac Pink, Potomac Red, Potomac Rose, Potomac Royal, Potomac Soft Yellow, Rocket Lemon, and Rocket White. Each bed was established with one cultivar, and cultivars were arranged randomly within each plot.

Plant beds were prepared and maintained according to standard commercial production practices, including annual fumigation with methyl bromide and amendment with a granular application of metalaxyl (Subdue GR; Syngenta Professional Products, Greensboro, NC) prior to planting. Plantings were maintained with foliar insecticide and fungicide applications according to commercial standards. Copper sulfate pentahydrate (Phyton 27; Phyton Corporation, Edina, MN), azoxystrobin (Heritage 50 WG; Syngenta Professional Products, Greensboro, NC), mancozeb (Dithane WF; Dow AgroSciences LLC, Indianapolis, IN), iprodione (Iprodione Pro 2SE; BASF Specialty Products, Mount Olive, NJ), fenhexamid (Decree 50 WDG; Arvesta Corp., San Francisco, CA), fosetyl-Al (Aliette; Rhone-Poulenc Research Triangle Park, NC), chlorothalonil (Daconil; Zeneca, Inc., Wilmington, DE), and myclobutanil (Systhane WSP; Dow AgroSciences LLC, Indianapolis, IN) were applied sporadically at labeled rates during the growing season. Plots were watered as needed (three to six times/week) via solid-set sprinkler irrigation set $1.3 \mathrm{~m}$ above the ground. Research plots remained in commercial production throughout the experiment and were hand harvested regularly as flower heads matured.

Environment and disease assessment. A Neogen EnviroCaster (Neogen, Mason, MI) sensor placed in an aisle at the center of each plot approximately $1 \mathrm{~m}$ above the ground recorded temperature, rainfall, and relative humidity every $15 \mathrm{~min}$ and calculated averages hourly. One Neogen EnviroCaster leaf wetness sensor, set at a $45^{\circ}$ angle, was placed in a planting bed within the plant canopy and raised as the plants grew.

Plants were naturally infected with downy mildew. Disease was assessed on 5 January, 2 and 25 February, 18 March, 14 April, and 5 May 2000 and on 7 and 22 March, 3 and 17 April, and 8 May 2001. Disease incidence was based on visual estimates of the percentage of diseased plants within each plant bed. Each plant bed was divided into $103.0-\mathrm{m}$ sections. Alternate sections within each bed were assessed, excluding end sections.

Conidia concentration determination. Concentrations of airborne sporangia were volumetric spore sampler (Burkard Mfg. Co. Ltd., Rickmansworth, Herfordshire, England) placed between the two sections of each plot from 2 December 1998 to 12 April 1999, 2 December 1999 to 11 April 2000, and 15 December 2000 to 12 April 2001 (Julian Day [JD] 336 to 102 was monitored each year). The spore samplers were operated at a flow rate of $10 \mathrm{li}$ ters/min and the orifice was free to move with changing wind direction. Sporangia were impacted onto tapes coated with an adhesive mixture of petroleum jelly and monitored in each plot using a 7-day

paraffin (9:1, wt/wt) dissolved in sufficient toluene to give a thick, liquid consistency. Tapes were removed weekly, cut into 48$\mathrm{mm}$ lengths, marked at 2-mm intervals with a razor blade to indicate hourly intervals, stained ( $28 \mathrm{mg}$ of aniline blue, $20 \mathrm{ml}$ of distilled water, $0.01 \mathrm{ml}$ of glycerol, and $10 \mathrm{ml}$ of $85 \%$ lactic acid, diluted with five drops to $25 \mathrm{ml}$ of distilled water), and mounted on glass slides beneath 22-by-50$\mathrm{mm}$ coverslips. Under a compound microscope $(\times 200)$, sporangia were identified as P. antirrhini based on size (23 to 30 by 14 to18 $\mu \mathrm{m})$ and ellipsoid to ovoid shape (8). The number of sporangia sampled during each 1-h period were recorded. When sporangial concentrations were exceptionally large $\left(>2,000 / \mathrm{m}^{3} / \mathrm{h}\right)$, a portion of the $2-\mathrm{mm}$ interval was counted and multiplied by the appropriate factor to provide an estimate of the concentration for the $1-\mathrm{h}$ period. Counts were converted to numbers of sporangia per cubic meter of air sampled per hour. PROC CORR (SAS Institute Inc., Cary, NC) was used to determine any positive or negative correlations among atmospheric sporangial concentration, total rainfall, leaf wetness, and temperature for each growing season.

\section{RESULTS}

Atmospheric sporangial concentrations. Each year, sporangia were detected in the atmosphere within 3 weeks (by JD 356) of spore-trapping initiation. Overall, total sporangial concentrations were much lower in 1999 and 2001 compared with 2000 (Figs. 1 and 2). Hourly averages of airborne sporangia were greatest during 0500 to $1200 \mathrm{~h}$ (Fig. 1). Within each year, peak concentrations hourly occurred at $0700 \mathrm{~h}$ in $2000\left(201\right.$ sporangia $\left./ \mathrm{m}^{3} / \mathrm{h}\right)$ and

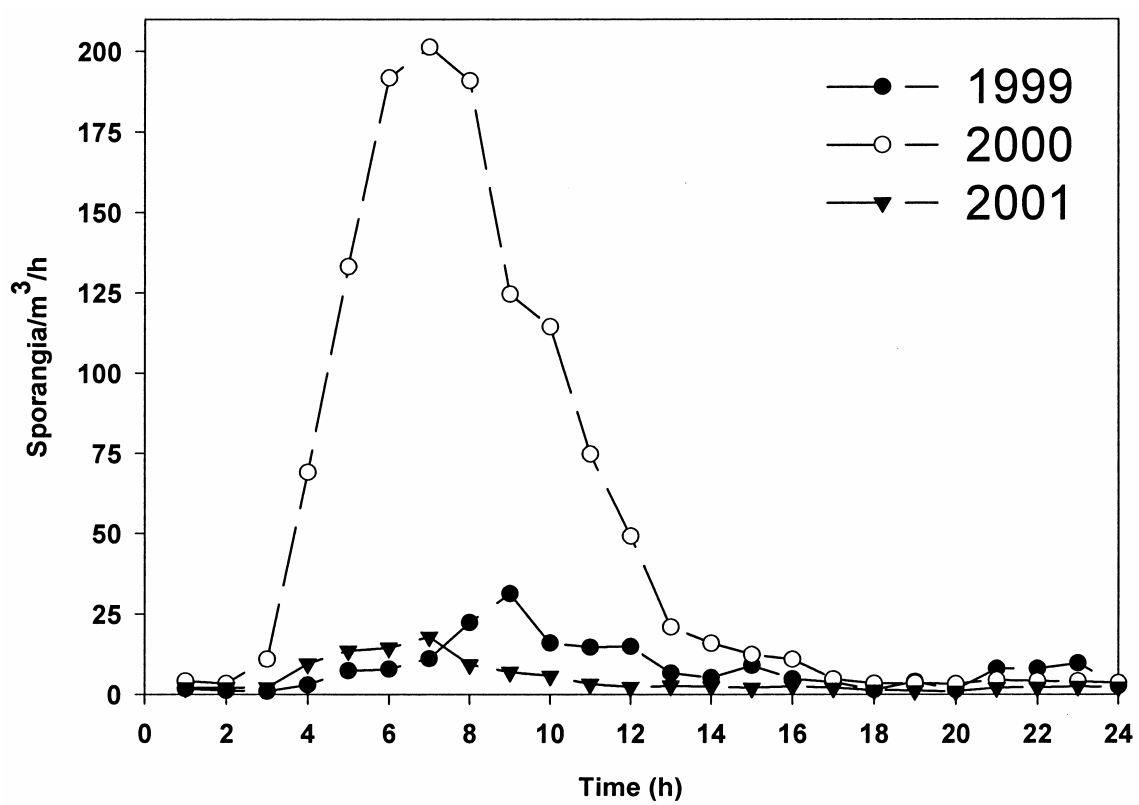

Fig. 1. Hourly average concentration of airborne sporangia of Peronospora antirrhini in research plots from 2 December 1998 to 15 April 1999, from 23 November 1999 to 5 May 2000, and from 14 December 2000 to 18 April 2001. 
2001 (18 sporangia $\left./ \mathrm{m}^{3} / \mathrm{h}\right)$, and at $0900 \mathrm{~h}$ (31 sporangia $/ \mathrm{m}^{3} / \mathrm{h}$ ) in 1999 (Fig. 1). Few sporangia $\left(<12\right.$ sporangia $\left./ \mathrm{m}^{3} / \mathrm{h}\right)$ were trapped between 1500 and $0300 \mathrm{~h}$, irrespective of year.

Temperature effects. Temperature did not have a significant correlation $(P>$ $0.05)$ with total spore count except for 2001 for maximum daily temperatures (MaxDTs; Table 1). However, minimum daily temperatures (MinDTs) $<10.0^{\circ} \mathrm{C}$ appeared to have a moderately limiting effect on atmospheric sporangial concentrations, whereas temperatures $<6.0^{\circ} \mathrm{C}$ had more severe limiting effects (Table 2). Temperatures were $<6.0^{\circ} \mathrm{C}$ on 6,9 , and 22 days in the 1999, 2000, and 2001 growing seasons, respectively. Immediately after
MinDTs $<6.0^{\circ} \mathrm{C}$ occurred in January of the 1999 growing season (weeks 5 to 6), the total weekly sporangia trapped during week 7 decreased significantly. MinDTs $<6.0^{\circ} \mathrm{C}$ also occurred in February 1999 (weeks 12 to 15), and a significant drop in atmospheric sporangia occurred in weeks 13 to 16 . In 2000 , the total weekly sporangia trapped remained low $\left(<103 / \mathrm{m}^{3} /\right.$ week $)$ until after week 11 . From week 12 to week

Table 1. Pearson correlation coefficients testing relationship between total weekly spore count, rainfall, hours $\geq 30^{\circ} \mathrm{C}$, hours $<10^{\circ} \mathrm{C}$, and hours $<6^{\circ} \mathrm{C}$ in 1999,2000 , and 2001

\begin{tabular}{lrccc}
\hline & \multicolumn{4}{c}{ Pearson correlation coefficients, $\boldsymbol{r}(\text { probability, } \boldsymbol{P})^{\mathbf{a}}$} \\
\cline { 2 - 5 } Factor & $\mathbf{1 9 9 9}$ & $\mathbf{2 0 0 0}$ plot 1 & $\mathbf{2 0 0 0 , \text { plot 2 }}$ & $\mathbf{2 0 0 1}$ \\
\hline Rainfall & $0.07113(0.7791)$ & $0.45513(0.0502)^{*}$ & $0.53852(0.0174)^{*}$ & $-0.17323(0.5061)$ \\
Hours $\geq 30^{\circ} \mathrm{C}$ & $-0.14265(0.5723)$ & $-0.04657(0.8498)$ & $-0.06074(0.8049)$ & $-0.48351(0.0493)^{*}$ \\
Hours $<10^{\circ} \mathrm{C}$ & $0.38620(0.1134)$ & $-0.27154(0.2608)$ & $-0.38402(0.1045)$ & $-0.38370(0.1284)$ \\
Hours $<6^{\circ} \mathrm{C}$ & $0.05364(0.8326)$ & $-0.16658(0.4955)$ & $-0.23121(0.3409)$ & $-0.32072(0.2094)$ \\
\hline
\end{tabular}

a Probability of a greater absolute value of $r$ between total weekly spore count and the following factors; * = significant correlation $(P \leq 0.05)$ between factor and total spore count.

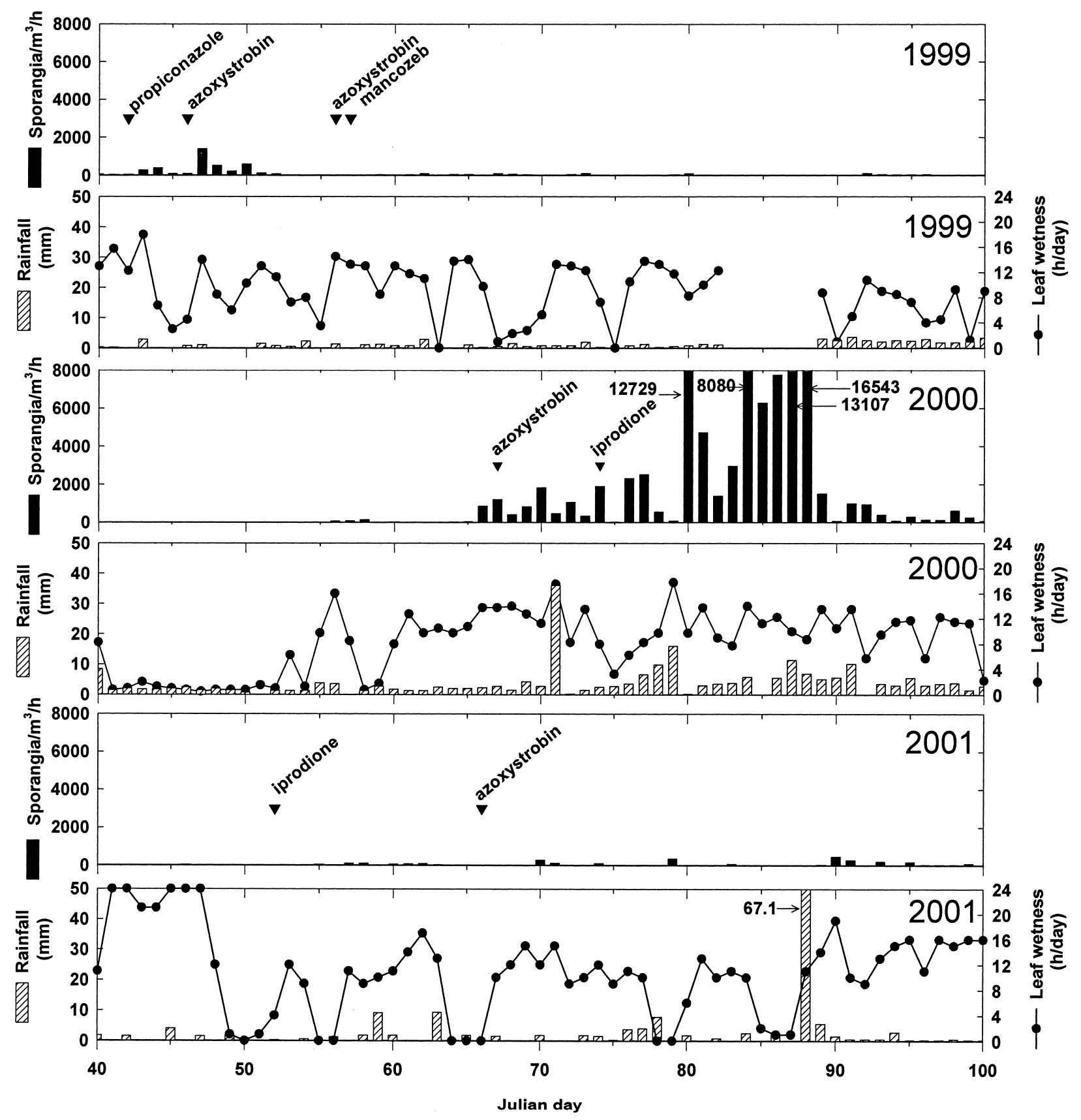

Fig. 2. Association of concentration of airborne sporangia of Peronospora antirrhini in snapdragon fields with rainfall and leaf wetness from 9 February to 10 April 1999, 9 February to 9 April 2000, and 9 February to 10 April 2001. Major ticks represent midnight and minor ticks represent midday. 
19 , temperatures were higher and weekly sporangial counts increased, reaching nearly $30,000 / \mathrm{m}^{3} /$ week. In 2001, a MinDT $<10.0^{\circ} \mathrm{C}$ occurred in each month of the observation period for a total of 39 days, and temperatures were as low as $-1.7^{\circ} \mathrm{C}$ in January. When temperatures $<6.0^{\circ} \mathrm{C}$ occurred for 12 consecutive days in January 2001 (weeks 5 to 6), total sporangia trapped per week did not exceed $30 / \mathrm{m}^{3} /$ week. Four days of MinDTs below $10.0^{\circ} \mathrm{C}$ in March 2001 (week 14) were accompanied by a weekly atmospheric sporangia total of $119 / \mathrm{m}^{3} /$ week.

MaxDTs $\geq 30.0^{\circ} \mathrm{C}$ also appeared to limit concentrations of atmospheric sporangia. The periods of leaf wetness that occurred on these warm days were adequate $(>8 \mathrm{~h})$ for sporangium development. Temperatures were $\geq 30.0^{\circ} \mathrm{C}$ for 4,5 , and 16 days in 1999, 2000, and 2001, respectively. In 1999, high temperatures occurred in the last 4 days of monitoring and no sporangia were trapped on these days. MaxDTs of 30.7 and $30.5^{\circ} \mathrm{C}$ and average daily temperatures of 23.5 and $25.3^{\circ} \mathrm{C}$ occurred on 30 and 31 March 2000, respectively (JD 90 to 91 , week 18). For the 6 days prior to these high temperatures, daily atmospheric sporangium totals were $>250 / \mathrm{m}^{3} /$ day, and sporangium totals did not reach this level again for 5 days, despite moderate rainfall ( 3.1 to $5.6 \mathrm{~mm}$ ) and adequate leaf wetness (6 to $13 \mathrm{~h}$ ). In 2001, MaxDTs $\geq 30.0^{\circ} \mathrm{C}$ occurred sporadically throughout the growing season (March and April) and on the last 3 days of monitoring. Atmospheric sporangial concentrations were reduced to at least $50 \%$ of the previous day's concentration on days immediately following 8 of the 9 days with MaxDT $\geq 30.0^{\circ} \mathrm{C}$.

Leaf wetness and rain. There was a relatively high amount of rain in 2000 , and a significant $(P<0.05)$ positive correlation between total rainfall and total spore count was observed (Fig. 2). Total rainfall was $309.8,424.7$, and $281.6 \mathrm{~mm}$ in 1999, 2000, and 2001, respectively. Leaf wetness often was detected beginning at $1900 \mathrm{~h}$ and persisted throughout the night, with leaves usually drying by $0700 \mathrm{~h}$ (Fig. 3). Long periods of leaf wetness ( $\geq 6 \mathrm{~h}$ ) were associated with relatively large sporangial releases at the end of the leaf wetness period when a reduction in relative humidity was noted (Fig. 3). Occasionally, sporangial releases were observed after a brief $(\leq 4 \mathrm{~h})$ leaf wetness period. When leaf wetness duration was short (average $2.7 \mathrm{~h}$ ), the daily totals of sporangia were relatively low. Atmospheric sporangial concentrations were suppressed immediately following consecutive days (two to three) with short leaf wetness periods. Short, midday leaf wetness periods, frequently caused by irrigation, did not appear to impact subsequent sporangial releases (Fig. 3).

Disease incidence. In 2000, until 18 March (JD 78), the average disease incidence was $<10 \%$. Between JD 78 and 109 ,
Table 2. Association of total numbers of sporangia of Peronospora antirrhini with high and low temperatures from 2 December 1998 to 12 April 1999, 2 December 1999 to 11 April 2000, and 15 December 2000 to 12 April $2001^{\text {a }}$

\begin{tabular}{|c|c|c|c|c|c|}
\hline Year, week no. & Julian day & $\begin{array}{l}\text { Total rainfall } \\
\quad(\mathbf{m m})\end{array}$ & $\begin{array}{l}\text { Hours } \\
<10^{\circ} \mathrm{C}\end{array}$ & $\begin{array}{l}\text { Hours } \\
<6^{\circ} \mathrm{C}\end{array}$ & $\begin{array}{c}\text { Total sporangia } \\
\left(\mathrm{m}^{3} / \text { week }\right)\end{array}$ \\
\hline \multicolumn{6}{|l|}{ 1998-99 } \\
\hline 1 & $336-342$ & 9.9 & 0 & 0 & 0 \\
\hline 2 & $343-349$ & 13.0 & 0 & 0 & 3 \\
\hline 3 & $350-356$ & 11.2 & 28 & 0 & 1 \\
\hline 4 & $357-363$ & 38.6 & 0 & 0 & 244 \\
\hline 5 & $364-05$ & 48.7 & 32 & 9 & 292 \\
\hline 6 & $06-12$ & 5.3 & 37 & 8 & 413 \\
\hline 7 & 13-19 & 10.4 & 0 & 0 & 53 \\
\hline 8 & $20-26$ & 20.3 & 0 & 0 & 82 \\
\hline 9 & $27-33$ & 18.3 & 0 & 0 & 30 \\
\hline 10 & $34-40$ & 11.9 & 0 & 0 & 284 \\
\hline 11 & $41-47$ & 23.9 & 23 & 0 & 2,280 \\
\hline 12 & $48-54$ & 7.1 & 29 & 2 & 1,502 \\
\hline 13 & $55-61$ & 12.2 & 34 & 1 & 60 \\
\hline 14 & $62-68$ & 18.3 & 21 & 8 & 295 \\
\hline 15 & 69-75 & 19.1 & 14 & 1 & 188 \\
\hline 16 & $76-82$ & 11.9 & 2 & 0 & 143 \\
\hline 17 & $83-89$ & $\ldots$ & $\ldots$ & $\ldots$ & $\ldots$ \\
\hline 18 & $90-96$ & 18.3 & 0 & 0 & 238 \\
\hline 19 & $97-102$ & 11.4 & 0 & 0 & 0 \\
\hline \multicolumn{6}{|l|}{ 1999-2000 } \\
\hline 1 & $336-342$ & 10.7 & 10 & 0 & $0^{\mathrm{b}}$ \\
\hline 2 & $343-349$ & 12.4 & 0 & 0 & 0 \\
\hline 3 & $350-356$ & 45.5 & 0 & 0 & 24 \\
\hline 4 & $357-363$ & 10.2 & 47 & 7 & 103 \\
\hline 5 & $364-05$ & 13.0 & 15 & 0 & 68 \\
\hline 6 & $06-12$ & 11.0 & 5 & 0 & 36 \\
\hline 7 & $13-19$ & 13.7 & 8 & 0 & 39 \\
\hline 8 & $20-26$ & 34.0 & 54 & 25 & 82 \\
\hline 9 & $27-33$ & 12.2 & 30 & 12 & 29 \\
\hline 10 & $34-40$ & 34.5 & 30 & 4 & 9.0 \\
\hline 11 & $41-47$ & 13.2 & 29 & 4 & 71.0 \\
\hline 12 & $48-54$ & 10.9 & 0 & 0 & 48 \\
\hline 13 & $55-61$ & 14.5 & 0 & 0 & 336 \\
\hline 14 & $62-68$ & 14.5 & 0 & 0 & 3,349 \\
\hline 15 & $69-75$ & 50.3 & 0 & 0 & 5,334 \\
\hline 16 & $76-82$ & 42.9 & 0 & 0 & 15,936 \\
\hline 17 & $83-89$ & 38.5 & 0 & 0 & 29,970 \\
\hline 18 & $90-96$ & 31.0 & 0 & 0 & 1,772 \\
\hline 19 & $97-102$ & 11.7 & 7 & 0 & 1,024 \\
\hline \multicolumn{6}{|l|}{$2000-01$} \\
\hline 1 & $336-342$ & $\ldots$ & $\ldots$ & $\ldots$ & $\ldots$ \\
\hline 2 & $343-349$ & $\ldots$ & $\ldots$ & $\ldots$ & $\ldots$ \\
\hline 3 & $350-356$ & 6.4 & 44 & 22 & 15 \\
\hline 4 & $357-363$ & 14.2 & 0 & 0 & 36 \\
\hline 5 & $364-05$ & 16.5 & 107 & 71 & 11 \\
\hline 6 & $06-12$ & 19.8 & 69 & 31 & 30 \\
\hline 7 & $13-19$ & 8.6 & 6 & 0 & 73 \\
\hline 8 & $20-26$ & 9.7 & 65 & 32 & 20 \\
\hline 9 & $27-33$ & 3.6 & 34 & 12 & 33 \\
\hline 10 & $34-40$ & 54.1 & 10 & 0 & 12 \\
\hline 11 & $41-47$ & 7.1 & 0 & 0 & 73 \\
\hline 12 & $48-54$ & 5.1 & 0 & 0 & 56 \\
\hline 13 & $55-61$ & 14.0 & 0 & 0 & 389 \\
\hline 14 & $62-68$ & 13.0 & 28 & 0 & 119 \\
\hline 15 & $69-75$ & 5.3 & 0 & 0 & 506 \\
\hline 16 & $76-82$ & 18.5 & 4 & 0 & 400 \\
\hline 17 & $83-89$ & 77.5 & 0 & 0 & 119 \\
\hline 18 & $90-96$ & 6.4 & 0 & 0 & 1,188 \\
\hline 19 & $97-102$ & 1.8 & 0 & 0 & 203 \\
\hline
\end{tabular}

a Fungicides were applied as follows: in 1998-99, azoxystrobin (JD 21, 46, 56), chlorothalonil (JD 12, 39, 344), copper sulfate pentahydrate (JD 356), fosety-Al (JD 7, 10), mancozeb (JD 7, 10, 27, 39, 57), myclobutanil (JD 344), propiconazole (JD 42, 351), and thiophanate-methyl (JD 27); in 19992000, azoxystrobin (JD 21, 67, 364), chlorothalonil (JD 19, 341), fosetyl-Al (JD 7, 335), iprodione (JD 74), and mancozeb (JD 7); and in 2000-01, azoxystrobin (JD 66, 360), copper hydroxide (JD 1), fosetyl-Al (JD 23), iprodione (JD 52), mancozeb (JD 1, 355), myclobutanil (JD 25), propiconazole (JD 18), and thiophanate-methyl (JD 355); ... indicates that no data were recorded for that particular week.

b Average number of sporangia for plots 1 and 2 from 22 November 1999 to 5 May 2000. 
the fourth and fifth disease ratings in the 2000 growing season, the duration of leaf wetness consistently averaged $12 \mathrm{~h}$ each night. Disease incidence was highest for Rocket White at the 14 April (JD 105) rating when the average disease incidence was $44.4 \%$. Older foliage that was enclosed within the canopy and foliage higher on the stalks was infected, and sporulation was heavy on both sides of the leaves. Disease incidence decreased after the fifth rating (JD 109). In 2001, disease incidence ranged between 2 and $28 \%$ at the first rating date, JD 66 . There was a slight increase in disease incidence between JD 66 and 93. However, there was no increase in disease incidence after JD93, during a relatively dry period. Disease incidence varied by cultivar, and these results have been published previously (4).

\section{DISCUSSION}

In this study, concentrations of atmospheric sporangia of $P$. antirrhini followed a diurnal cycle. Sporulation of many downy mildews is dependent on cycling of light and darkness: continuous light or darkness prevents the sporulation of $B$. lactucae, $P$. destructor, Plasmopara viticola, and Pseudoperonospora humuli $(30,32)$. Timing of the sporulation process (sporangiophore emergence, differentiation, sporangial formation, maturation, and spore liberation) varies with species. The sporulation process of Peronospora antirrhini appeared to be completed earlier and perhaps more quickly than other downy mildew pathogens. Sporangial release in our study began at $0500 \mathrm{~h}$ and, in 1999 and 2001, peak sporangial concentrations occurred at $0700 \mathrm{~h}$. Field observations of Pseudoperonospora humuli determined that conidiophores emerged from stomata by midnight, differentiation was complete and small conidia formed by $0300 \mathrm{~h}$, conidia were full sized at $0600 \mathrm{~h}$, and conidia were mature and being liberated at $0900 \mathrm{~h}$ (32).

Several mechanisms may be involved in the liberation of sporangia; however, the timing of peak daily releases in our study appeared to be associated with decreasing relative humidity and increasing temperature. These factors tend to follow diurnal patterns and could not be evaluated independently in this field study. Hildebrand and Sutton (10) found that peak releases of Peronospora destructor occurred as relative humidity dropped, leaf wetness evaporated, and wind speeds increased. However, in field studies of B. lactucae, low numbers of spores were released on mornings with prolonged leaf wetness and high relative humidity (28). Red-infrared radiation and solar radiation have been implicated as triggers of spore release under such conditions $(23,28)$.

MinDTs $<6.0^{\circ} \mathrm{C}$ occurred periodically in all three growing seasons, temporarily reducing atmospheric sporangial concentrations. Average MinDT is an important component in disease prediction of other downy mildew pathogens. An analysis of environmental factors over a 28 -year period of hop production determined that MinDTs generally were higher in April and May of years with severe epidemics of Pseudoperonospora humuli than in years with mild or no epidemics (14).

MaxDTs $>30.0^{\circ} \mathrm{C}$ limited atmospheric sporangial concentrations. This coincides with Yarwood's (33) earlier observations that sporulation of Peronospora antirrhini occurred on systemically infected plants
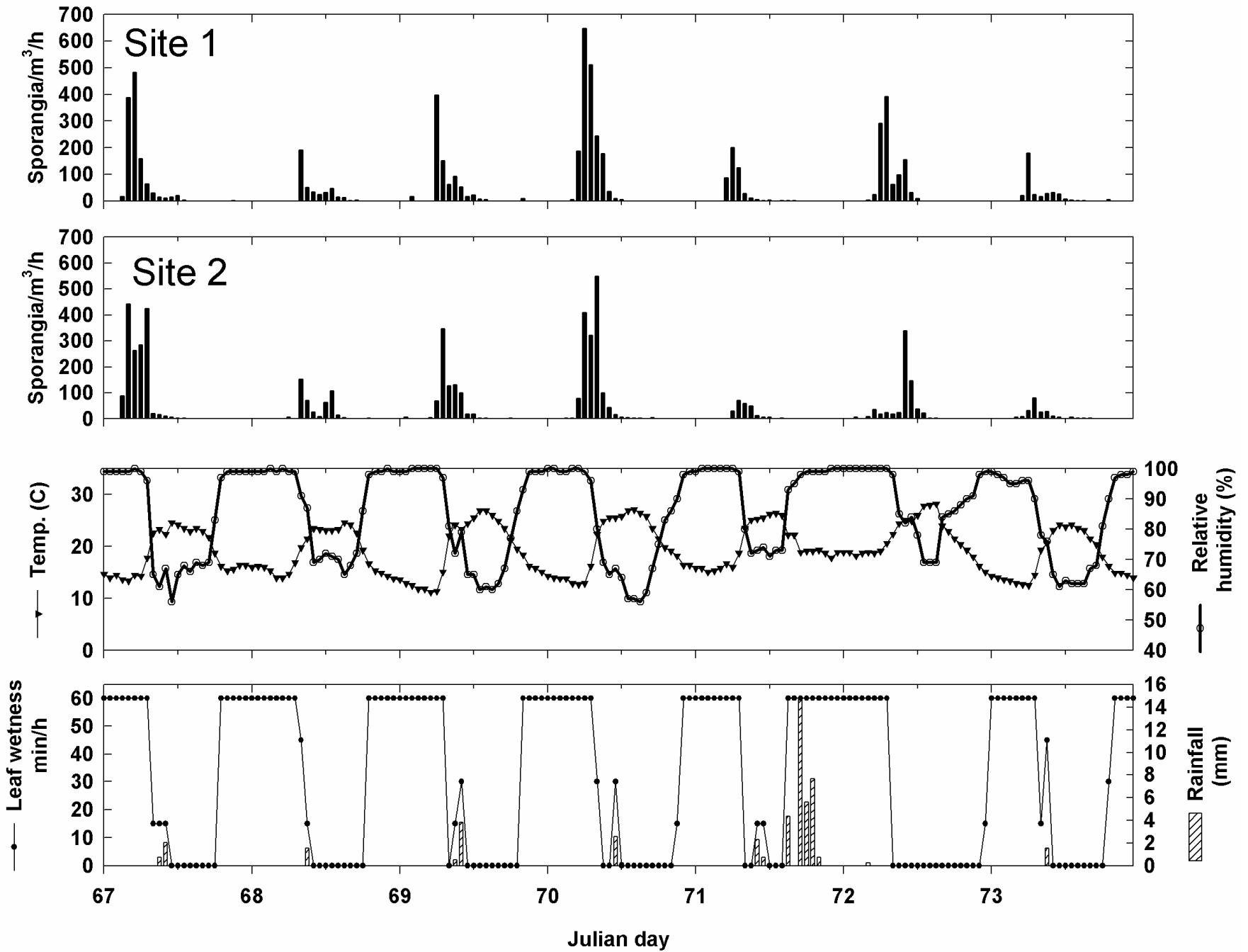

Fig. 3. Association of concentration of airborne sporangia of Peronospora antirrhini in snapdragon fields with temperature, relative humidity, leaf wetness, and rainfall in plots 1 and 2 during 7 through 14 March 2000. Major ticks represent midnight and minor ticks represent midday. 
incubated at 13 and $19^{\circ} \mathrm{C}$, but not on those incubated at $22^{\circ} \mathrm{C}$. Additionally, Yarwood observed that inoculations during the winter and early spring months were more successful than inoculations during the hotter summer months (33). In our study, sporulation was reduced when MaxDTs were at least $30.0^{\circ} \mathrm{C}$, even though sporangiophores are not likely to initiate until evening.

In this study, the greatest number of consecutive days with high temperatures occurred at the end of each monitoring period, and atmospheric sporangial concentrations decreased progressively during these times. The same trend has been reported with $P$. tabacina, which has a higher temperature tolerance (21). Increased temperature, increased maturity of the tobacco tissue, and reduction in available tissue due to harvesting all were thought to be involved in the decrease in disease incidence that occurred at the end of the growing seasons.

Brief periods of leaf wetness due to irrigation did not have a notable effect on the atmospheric sporangial concentrations, yet a significant positive correlation was found between total rainfall and total spore count in 2000. The relatively high amount of rain in 2000 may explain the explosive concentration of spores that occurred that year. There was more rain during 2000 than in 1999 and 2001, and also higher concentrations of airborne sporangia in 2000 (Fig. 3 ). Yarwood (33) concluded that rain did not play an important role in the disease progress of $P$. antirrhini based on his observations that epidemics in the greenhouse were more significant than those on outdoor plantings. Rainy weather was unfavorable for the sporulation of $P$. $d e$ structor; sporulation failed to occur on 8 of 10 nights that otherwise were considered favorable based on the relative humidity and temperature (10). Rainfall events alone may not be conducive for disease, but a long leaf wetness duration that follows rainy weather can increase spore release (28). Heavy rainfall significantly increased $P$. humuli conidial release and infection on hop (13). In Africa, downy mildew of maize and sorghum, Peronosclerospora sorghi, was significantly increased $(29 \%$ incidence) with heavy rainfall $(1,500 \mathrm{~mm})$ and decreased $(<5 \%$ incidence) with rainfall $<1,300 \mathrm{~mm}$ (2). Further, rainfall can initiate oospore germination and primary infections, increasing downy mildew incidence (31).

The duration of leaf wetness at night affected the number of atmospheric sporangia trapped on the subsequent day. Among the three growing seasons, there were 69 days where the daily total of sporangia was $\geq 100 / \mathrm{m}^{3} /$ day. The average length of leaf wetness durations on the evenings prior to these relatively large releases was $11 \mathrm{~h}$. There were several occasions where limited leaf wetness ( 0 to $3 \mathrm{~h})$ directly pre- ceded sizable (20 to $100 / \mathrm{m}^{3} /$ day) releases. However, it was noted that these days followed an extended leaf wetness period (11 to $16 \mathrm{~h}$ ) that occurred on the prior day. A dry night in the middle of a series of days with high concentrations of atmospheric sporangia resulted in a decreased spore release on the following day. This also has been observed with epidemics caused by $P$. tabacina (22).

When leaf wetness is prolonged and overlaps with sporangial release, infection likely is favored. Field studies of B. lactucae determined that morning leaf wetness durations were consistent predictors of infection days (26). Scherm and van Bruggen (26) found that morning leaf surface wetness was the most critical factor in predicting disease, and they further concluded that morning leaf wetness duration could be used in a decision support system for lettuce downy mildew management. Infection periods occurred mainly on days in which leaf wetness ended late in the morning (1000 h or later; 28 ).

Although MaxDT, MinDT, relative humidity, and leaf wetness are important factors in downy mildew development, a favorable level of one may compensate for a marginal level in the other (13). This compensation of one environmental requirement for another in downy mildew is one of the reasons that accurate and effective disease prediction models for other downy mildew pathogens have been slow to be developed. Variability in disease susceptibility also complicates development of a disease predictive model that prompts fungicide application; this has been a problem with other downy mildew predictive models. For example, in grape production, the relationship between temperature, wetness duration, and relative humidity and the resulting infection and sporulation depends on the grape species or hybrid (18). From this study and other downy mildew studies, it is difficult to discern whether differences in spore release are attributed to relative humidity, leaf wetness, or rainfall or are due to the overlapping and interrelation of these variables. Differing climates in various production areas of the world also prevent widespread adoption of existing disease prediction systems. For example, monitoring systems used in European grape production are too conservative for use in the midwestern United States (18), and models for hop downy mildew used in Europe are not used in the western United States because the environmental factors that restrict disease development differ in the two locations. It is our intent that information gained from this study will help growers understand the relationship between environment and disease development, and that it will be incorporated into current disease management programs, enhancing their effectiveness. Despite previous difficulties in creating downy mildew predictive sys- tems in other crops, further research examining leaf wetness, relative humidity, and rainfall effects on releases of $P$. antirrhini sporangia could aid in developing a disease prediction model and disease management program for snapdragon production areas in the United States.

\section{LITERATURE CITED}

1. Anonymous. 2004. USDA National Agricultural Statistics Service. Floriculture Crops 2003 Summary. Sp Cr 6-1 (04)a.

2. Bock, C. H., Jeger, M. J., Mughoho, L. K., Cardwell, K. F., Adenle, V., Mtisi, E., Akpa, A. D., Kaula, G., Mukasambina, D., and BlairMyers, C. 1998. Occurrence and distribution of Peronosclerospora sorghi (Weston and Uppal (Shaw)) in selected countries of west and southern Africa. Crop Prot. 17:427-439.

3. Brown, S., Koike, S. T., Ochoa, O. E., Laemmlen, F., and Michelmore, R. W. 2004 Insensitivity to the fungicide fosetyl-aluminum in California isolates of the lettuce downy mildew pathogen, Bremia lactucae. Plant Dis. 88:502-508.

4. Byrne, J. M., Sconyers, L. E., and Hausbeck, M. K. 2003. Evaluation of snapdragon cultivars for resistance to downy mildew, 2000 and 2001. Biol. Cult. Tests 19:O010. Online publication.

5. Davidson, C. R., Evans, T. A., Mulrooney, R. P., and Carroll, R. B. 2000. Evaluation of lima bean cultivars for resistance to downy mildew, 2000. Biol. Cult. Tests 16:V80. Online publication.

6. Erichsen, E. 1999. Problems in mildew control in northern Germany. Getreide 1:44-46.

7. Fitzgerald, C. B., Everts, K. L., and Newell, M. 2003. Evaluation of pumpkin cultivars under conventional and reduced risk fungicide programs. Biol. Cult. Test 19:V008.

8. Francis, S. M. 1981. Peronospora antirrhini. No. 685 in: CMI Descriptions of Pathogenic Fungi and Bacteria Set 69. Commonwealth Mycological Institute, Kew, Surrey, England.

9. Hausbeck, M. K. 2004. Downy mildew on impatiens in the UK...A problem for U.S.? Greenhouse Product News 14(3):34-38.

10. Hildebrand, P. D., and Sutton, J. C. 1982. Weather variables in relation to an epidemic of onion downy mildew Peronospora destructor, near Bradford, Ontario. Phytopathology 72:219-224.

11. Ishii, H., Fraaije, B. A., Sugiyama, T., Noguchi, K., Nishimura, T., Takeda, T., Amano, T., and Hollomon, D. W. 2001. Occurrence and molecular characterization of strobilurin resistance in cucumber powdery mildew and downy mildew. Phytopathology 91:1166-1171.

12. Ivey, M. L. L., Mera, J., and Miller, S. A. 2002. Response of radish cultivars to Rhizoctonia hypocotyl rot, clubroot and downy mildew, 2002. Biol. Cult. Tests 16:V013.

13. Johnson, D. A., Alldredge, J. R., and Allen, J. R. 1994. Weather and downy mildew epidemics of hop in Washington state. Phytopathology 84:524-527.

14. Johnson, D. A., Skotland, C. B., and Alldredge, J. R. 1983. Weather factors affecting downy mildew epidemics of hops in the Yakima Valley of Washington. Phytopathology 73:490-493.

15. Kucharek, T. A. 1987. Rainfall, irrigation water, and temperatures associated with first occurrences of tobacco blue mold in leaf production area of north Florida from 1979 to 1984. Plant Dis. 71:336-339.

16. Lalancette, N., Ellis, M. A., and Madden, L. V. 1988. Development of an infection efficiency model for Plasmopara viticola on American grape based on temperature and duration of leaf wetness. Phytopathology 78:794-800. 
17. Lalancette, N., Madden, L. V., and Ellis, M. A. 1988. A quantitative model for describing the sporulation of Plasmopara viticola on grape leaves. Phytopathology 78:1316-1321.

18. Madden, L. V., and Ellis, M. A. 2000. Evaluation of a disease warning system for downy mildew of grapes. Plant Dis. 84:549-554.

19. Madden, L. V., Hughes, G., and Ellis, M. A. 1995. Spatial heterogeneity of the incidence of grape downy mildew. Phytopathology 85:269275.

20. McKay, R. 1949. The production of oospores by the downy mildew of Antirrhinums. Gard. Chron. 28.

21. Moss, M. A., and Main, C. E. 1988. The effect of temperature on sporulation and viability of isolates of Peronospora tabacina collected in the United States. Phytopathology 78:110-114.

22. Nesmith, W. C. 1984. The North American blue mold warning system (Peronospora tabacina, tobacco). Plant Dis. 68:933-936.

23. Populer, C. 1981. Epidemiology of downy mildews. Pages 57-101 In: The Downy Mildews. D. M. Spencer, ed. Academic Press, London.

24. Santamaria, L., Evans, T. A., Pill, W. G., Davey, J., Mulrooney, R. P., and Carroll, R. B. 2003. Evaluation of lima bean cultivars for resistance to downy mildew, 2003. Biol. Cult. Tests 19:V016.

25. Scherm, H., Koike, S. T., Laemmlen, F. F., and van Bruggen, A. H. C. 1995. Field evaluation of fungicide spray advisories against lettuce downy mildew (Bremia lactucae) based on measured or forecast morning leaf wetness. Plant Dis. 79:511-516.

26. Scherm, H., and van Bruggen, A. H. C. 1994. Weather variables associated with infection of lettuce by downy mildew (Bremia lactucae) in coastal California. Phytopathology 84:860-865.

27. Scherm, H., and van Bruggen, A.H.C. 1994. Effects of fluctuating temperatures on the latent period of lettuce downy mildew (Bremia lactucae). Phytopathology 84:853-859.
28. Scherm, H., and van Bruggen, A. H. C. 1995. Concurrent spore release and infection of lettuce by Bremia lactucae during mornings with prolonged leaf wetness. Phytopathology 85:552-555.

29. Scherm, H., and van Bruggen, A. H. C. 1995. Comparative study of microclimate and downy mildew development in subsurface drip- and furrow-irrigated lettuce fields in California. Plant Dis. 79:620-625.

30. Weston, W. H. 1924. Nocturnal production of conidia by Sclerospora graminicola. J. Agric. Res. 27:771-784

31. Wheeler, B. E. J. 1981. Downy mildew of ornamentals. Pages 473-484 In: The Downy Mildews. D. M. Spencer, ed. Academic Press, London.

32. Yarwood, C. E. 1937. Relation of light to the diurnal cycle of sporulation of certain downy mildews. J. Agric. Res. 54:365-373.

33. Yarwood, C. E. 1947. Snapdragon downy mildew. Hilgardia 17:241-249. 